\title{
Influence of Tire Waste over Durability of Polymer Concrete
}

\author{
Bucur Roxana Dana, Barbuta Marinela, Harja Maria, Baran Irina
}

\begin{abstract}
Capitalization of tires waste is a priority problem determinate by the large quantities of these waste and environmental impact generated. In this paper we recommended capitalization with obtaining of new material with improved proprieties. The durability of a new polymer concrete with tires waste powder is presented in this paper.
\end{abstract}

Durability characteristics such as: water adsorption, the chemical resistance, frost thaw cycles resistance, and thermal shock strength were performed. Influence of resin content and filler content were analysed. Thermo-physical tests have shown a very good behaviour of epoxy concrete with tires powder subjected to different types of aggressive agents, compared with that of witness polymer concrete, without addition. Results show that polymer concrete with tire powder display a very good behaviour to: frost-thaw cycles, thermal shock and chemical attack.

The use of tires wastes in polymer concrete may help to improve the environment by elimination of a pollutant and to obtain a new composite material for construction industry.

This new composite which uses powder of waste tires is a lightweight concrete, with good durability properties, which can successfully replace the cement concrete in specific applications such as: prefabricated unit for sound protection, thermal insulation, floors for chemical industry, pavements, etc.

Keywords - durability, epoxy resin, polymer concrete, recycles, tire waste

\section{Introduction}

The disposal of used tires on landfill causes problem for the environment and public health. The European Association of Tyres and Rubber Producers estimates that in every year about 3.2 million tonnes of used tyres (part worn + end of life tyres) are generated in $\mathrm{EU} 27+\mathrm{NO}+\mathrm{CH}$, of which 2.5 million tonnes are either recycled or recovered. This amounts to approximately 250 million units. The recovery ratio was $96 \%$, of which $18 \%$ were retreated or reused, $38 \%$ were recycled and $40 \%$ were used for energy production [1-3]. In Romania the recovery ratio is upon $10 \%$, in this context capitalization is a challenge for researcher.

In the word the tire wastes are used for different kinds of purposes. They are frequently used whole by the construction industry and in agriculture. The tyres can be used in natural form, cut in aggregates or in powder. Rubber aggregate is often used in construction works for obtaining light concrete or for road pavements. The rubber increases the capacity to absorb energy from impacts, thus reducing the damage from collisions and increases the deformability and ductility of concrete.
Once asphalt-rubber mixtures started to be regulated in the 1990s their use in pavements increased significantly [4]. According to Adhikari et al. [4] the main advantages of pavements containing tires are their greater resistance to temperature variations and their better drainage.

In comparison with conventional building materials the composite containing polymers resin have improved properties [5, 6]. The composite concretes are characterized by great resistance to the chemical agents, good adhesion with the aggregates, fast hardening, etc [6, 7, 8]. The polymer concrete are recommended for applications in: repair works, precast elements, hydraulic structures, as a replacement for cast metals, in obtained of reservoirs and coating materials for the chemical and food industry etc.), in underground constructions, road surfaces, etc. [7, 8].

The most important binders of such concrete are: polyester, epoxy, furan, acrylic resins, polyurethane, etc. [3 9]. In polymer concrete mixture as filler can be used several types of wastes such as: silica fume, slag, fly ash, marble, powder of used tires, clay $[10,11,12,13,14]$. These fillers improve the properties of polymer concrete, and if the filler is an industrial by-product by capitalization it results the environmental protection [15-22].

The objectives of the study were to obtain new composite materials using tires wastes that are efficient as cost and helpful for the environment. Polymer concrete was combined with powder of used tires in different dosages and durability properties of this new product were analyzed in order to establish the application domain.

\section{Experimental Program}

\section{I.1 Material}

The polymer concrete was prepared with epoxy resin type ROPOXID produced in Romania by Policolor SA Bucuresti, powder of tires waste and two sorts of aggregates. A witness concrete containing $12.4 \%$ epoxy resin and aggregate of two sorts (43.8\% for each sort) was prepared for comparing the experimental results. The powder tires were obtained by cutting in small pieces, after that the steel insertions were eliminated and the cut pieces were transformed in powder.

The particles of tire powder are irregular shapes as it can see, in the SEM images presented in Figure 1. Density of powder is $1070-1080 \mathrm{~kg} / \mathrm{m}^{3}$.

The tire powder was characterized by granulometry with SALD-7001 laser diffractometer, mean diameter of the particles was $68.943 \mu \mathrm{m}$, Fig. 2.

The aggregates were river gravel, in two sorts: sort I (0-4 $\mathrm{mm})$ and sort II (4-8 $\mathrm{mm})$. 
Proc. of the Fourth International Conference on Advances in Civil, Structural and Environmental Engineering - ACSEE 2016. Copyright (C) Institute of Research Engineers and Doctors. All rights reserved.

ISBN: 978-1-63248-114-6 doi: 10.15224/ 978-1-63248-114-6-57
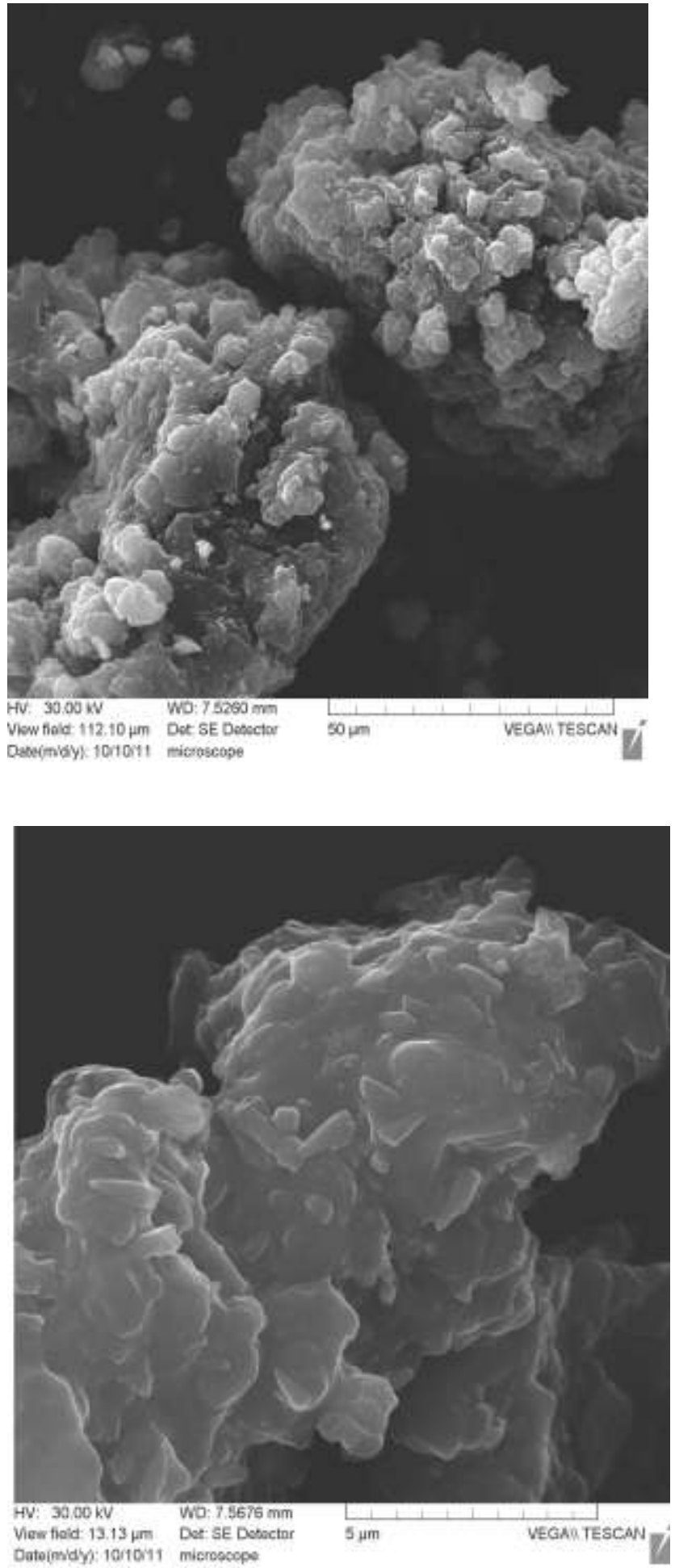
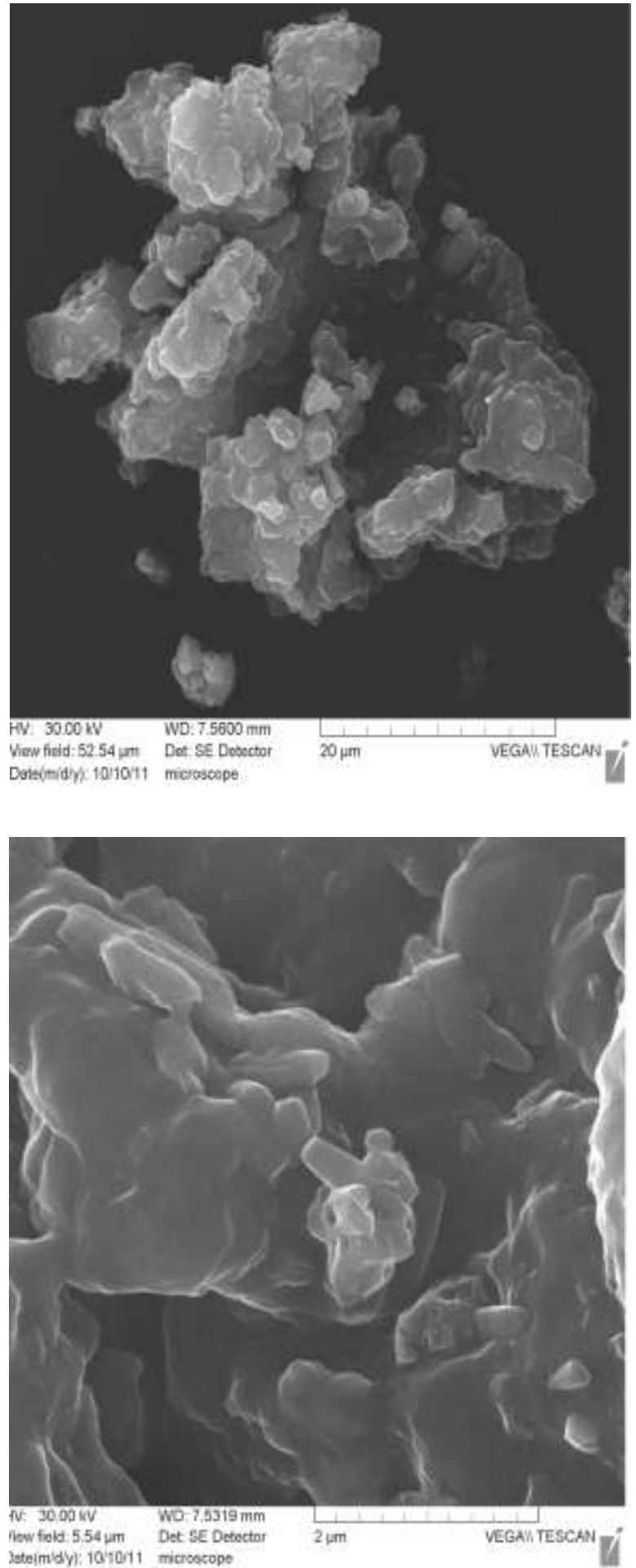

Fig. 1 SEM images for tires powder

\section{I.2 Mixtures}

For the experimental program 10 mixes were studied, Table 1, presented according to the statistical design of experiments, in which one condition was to use a reduced quantity of epoxy resin for obtaining of new materials with low cost. The minimum dosage of polymer was $17 \%$, imposed by the workability condition of the mixture. For preparing polymer concrete with tire powder, aggregates of two sorts were firstly mixed with the tire waste, considered as filler, after that, the epoxy resin and hardener were combined with aggregates and the polymer concrete was mechanically mixed. Cubes of $70 \mathrm{~mm}$ size and plates of $100 \times 100 \times 40 \mathrm{~mm}$ sizes were used for characterizing of polymer concrete with tire powder (PCP).

For witness concrete, the same samples were poured and they were tested in the same experimental conditions.

The tests were done according to Romanian standards [23-29]. 
Proc. of the Fourth International Conference on Advances in Civil, Structural and Environmental Engineering - ACSEE 2016. Copyright @ Institute of Research Engineers and Doctors. All rights reserved.

ISBN: 978-1-63248-114-6 doi: 10.15224/ 978-1-63248-114-6-57

$q_{0}(\%)$

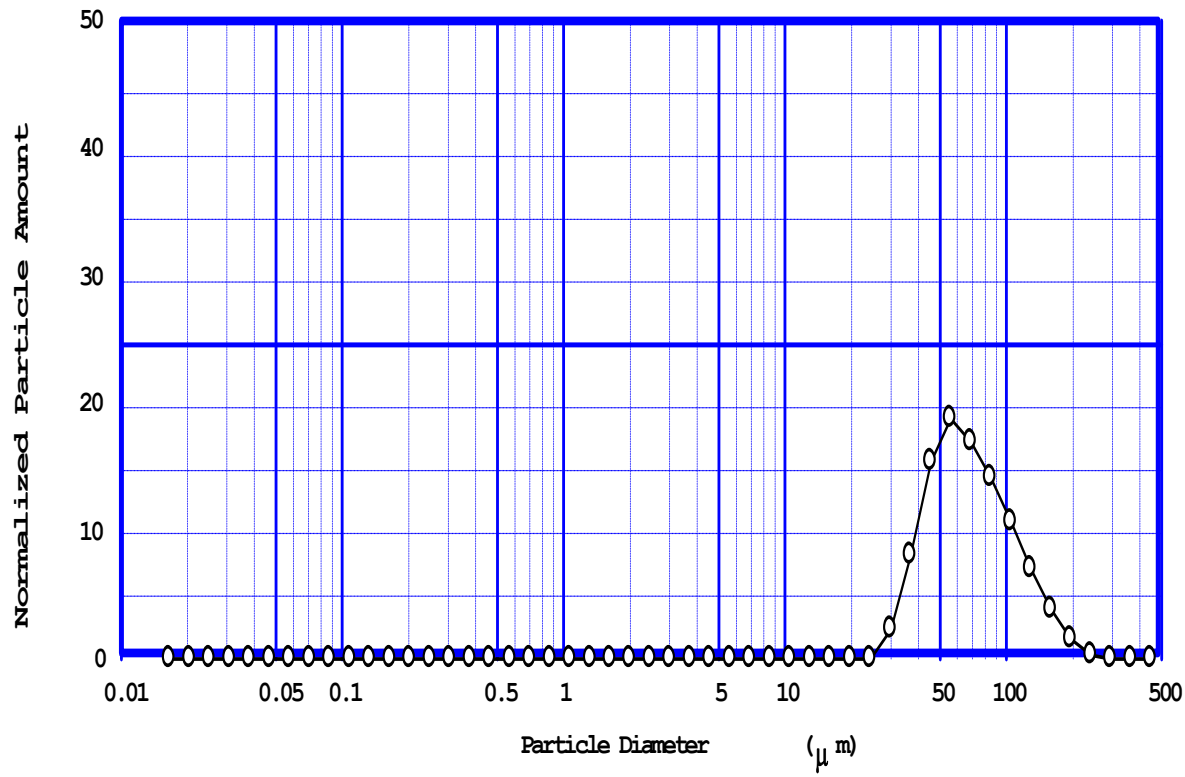

Fig. 2 Granulometrical distribution for tires powder.

\section{II.3 Experimental tests}

For characterizing the thermo-physical and durability properties the following tests were done: density of fresh and hardened concrete; thermal shock strength; chemical resistance; frost-thaw resistance and water adsorption.

TABLE I. COMPOSITION AND DENSITY OF POLYMER CONCRETE WITH TIRE POWDER

\begin{tabular}{|c|c|c|c|c|c|c|}
\hline Mixture & $\begin{array}{c}\text { Epoxy } \\
\text { resin } \\
\text { dosage }\end{array}$ & $\begin{array}{c}\text { Tire } \\
\text { powder }\end{array}$ & $\begin{array}{c}\text { Sort } \\
\text { I }\end{array}$ & $\begin{array}{c}\text { Sort } \\
\text { II }\end{array}$ & $\begin{array}{c}\text { Density of } \\
\text { fresh } \\
\text { concrete, } \\
\mathbf{k g} / \mathbf{m}^{\mathbf{3}}\end{array}$ & $\begin{array}{c}\text { Density of } \\
\text { hardened } \\
\text { concrete, } \\
\mathbf{k g} / \mathbf{m}^{\mathbf{3}}\end{array}$ \\
\hline PCP 1 & 0.23 & 0.17 & 0.3 & 0.3 & 1597 & 1606.0 \\
\hline PCP 2 & 0.17 & 0.23 & 0.3 & 0.3 & 1553 & 1554.0 \\
\hline PCP 3 & 0.17 & 0.17 & 0.36 & 0.3 & 1677 & 1689.1 \\
\hline PCP 4 & 0.17 & 0.17 & 0.3 & 0.36 & 1734.7 & 1755.3 \\
\hline PCP 5 & 0.2 & 0.2 & 0.3 & 0.3 & 1620.8 & 1710.3 \\
\hline PCP 6 & 0.2 & 0.17 & 0.33 & 0.3 & 1657.8 & 1672.1 \\
\hline PCP 7 & 0.2 & 0.17 & 0.3 & 0.33 & 1700.4 & 1723.7 \\
\hline PCP 8 & 0.17 & 0.2 & 0.33 & 0.3 & 1649.2 & 1692.7 \\
\hline PCP 9 & 0.17 & 0.2 & 0.3 & 0.33 & 1602.9 & 1625.3 \\
\hline PCP 10 & 0.17 & 0.17 & 0.33 & 0.33 & 1660 & 1700.1 \\
\hline
\end{tabular}

\section{Experimental Results}

\section{III.1. Density of fresh and hardened concrete}

The results regarding density for polymer concrete with tire powder are given in Table1. From Table 1 it can observed: $\mathrm{kg} / \mathrm{m}^{3}$

- medium value of density for fresh concrete is 1645 $\mathrm{kg} / \mathrm{m}^{3}$.

- medium value of density for hardened concrete is 1682

- density of witness fresh concrete is $2086 \mathrm{~kg} / \mathrm{m}^{3}$;
- density of witness hardened concrete is $1876 \mathrm{~kg} / \mathrm{m}^{3}$.

In conclusion, density of polymer concrete with tire powder was smaller than that of witness. Both types of concretes had for hardened concrete values which placed them into the category of lightweight concretes.

\section{III.2. Thermal shock strength}

The test was done according to SR EN ISO 105459:2000 [26] using the method by immersion. Five samples were used, the experimental results are presented in Table 2.

TABLE II. DETERMINATION OF THERMAL SHOCK RESISTANCE

\begin{tabular}{|c|c|c|c|c|c|}
\hline No. & $\begin{array}{c}\text { Initial } \\
\text { mass, g }\end{array}$ & $\begin{array}{c}\text { Mass after } \\
\text { water } \\
\text { absorption, }\end{array}$ & $\begin{array}{c}\text { Final mas } \\
\text { after testin } \\
\mathbf{g}\end{array}$ & $\begin{array}{c}\text { Loss of } \\
\text { mass, g }\end{array}$ & $\begin{array}{c}\text { Water } \\
\text { absorption, } \\
\text { \% }\end{array}$ \\
\hline Witness & 79.295 & 79.3201 & 78.591 & 0.7192 & 0.0316 \\
\hline 2 & 92.65 & 93.770 & 93.148 & 0.622 & 1.208 \\
\hline 3 & 89.78 & 90.588 & 89.98 & 0.608 & 0.899 \\
\hline 4 & 85.741 & 86.785 & 86.176 & 0.609 & 1.217 \\
\hline 5 & 91.035 & 92.041 & 91.394 & 0.647 & 1.105 \\
\hline
\end{tabular}

The average value obtained for water absorption was $0.01162 \%$.

Defects after testing: at visual examination from $30 \mathrm{~cm}$ distance and illumination of $3001 \mathrm{x}$ on a surface treated with methyl blue it was observed that all samples did not present modifications such as deformations, swelling, cracks, material dislocations or exfoliations. In conclusion the polymer concrete with tire powder had a very good behaviour to extreme values of temperature.

Because the witness had a bigger loss of mass, comparing with the witness, the behaviour of polymer concrete with tire powder was better. 
Proc. of the Fourth International Conference on Advances in Civil, Structural and Environmental Engineering - ACSEE 2016. Copyright @ Institute of Research Engineers and Doctors. All rights reserved.

ISBN: 978-1-63248-114-6 doi: 10.15224/ 978-1-63248-114-6-57

\section{III.3. Chemical resistance}

The tests were done according to SR EN ISO 1054513:2001 [27] on five samples, having the initial mass between: $115 \div 160 \mathrm{~g}$. The samples were dried to a constant mass in oven at a temperature of $80{ }^{\circ} \mathrm{C}$. Then the samples were kept for cooling 7 days at ambient temperature. For the tests the following solutions were used:

a) Solution of hydrochloric acid $(\mathrm{HCl}), 18 \%$;

b) Solution of potassium hydroxide $(\mathrm{KOH}), 100 \mathrm{~g} / \mathrm{L}$.

The samples were immersed into the solutions and kept in the laboratory during 12 days at a temperature of $(20 \pm 2)$ ${ }^{0} \mathrm{C}$. After that, the samples were exposed to stream during 5 days and then were boiled during 30 minutes. Then the samples were pulled out, were wiped and were dried at constant mass in oven at $80{ }^{\circ} \mathrm{C}$. After drying the samples were weighed and the loss of mass, $\Delta \mathrm{m}$, was determined. Then was determined the chemical resistance class (CRC) according to SR EN ISO 10545-13:2001 [27].

The tests of chemical resistance to the action of aggressive agents on polymer concrete with tire powder have established the following, Table 3.

Considering the hardness of the testing method (12 days) and high concentrations of very aggressive chemical agents $\mathrm{HCl}$ and $\mathrm{KOH}$ it can appreciate that the polymer concrete had a good chemical resistance. In all cases there were any defects on the polymer concrete, according to SR EN ISO 10545-13:2001 [27].

The witness polymer concrete presented a higher loss of mass compared with that of polymer concrete with tire waste, Table 3 .

TABLE III. DETERMINATION OF CHEMICAL RESISTANCE

\begin{tabular}{|c|c|c|c|c|c|c|}
\hline No & $\begin{array}{c}\text { Initial } \\
\text { Mass, g }\end{array}$ & $\begin{array}{c}\text { Mass } \\
\text { before } \\
\text { testing, g }\end{array}$ & $\begin{array}{c}\text { Constant } \\
\text { Mass } \\
\text { after } \\
\text { testing, g }\end{array}$ & $\begin{array}{c}\text { Loss of } \\
\text { mass } \\
\text { after } \\
\text { testing, } \\
\mathbf{g}\end{array}$ & $\begin{array}{c}\text { Loss } \\
\text { mass, } \\
\%\end{array}$ & Observations \\
\hline 1 & 131.029 & 130.817 & 127.5466 & 3.2704 & 2.25 & $\begin{array}{c}\text { Witness in } \\
18 \% \mathrm{HCl}\end{array}$ \\
\hline 2 & 144.8767 & 144.8664 & 141.941 & 2.9263 & 2.02 & $\begin{array}{c}\text { Witness in } \\
18 \% \mathrm{HCl}\end{array}$ \\
\hline 3 & 135.2487 & 135.2398 & 133.0935 & 2.1462 & 1.587 & $\begin{array}{c}\text { Witness in } \\
\text { KOH } 100 \mathrm{~g} / 1\end{array}$ \\
\hline 4 & 152.643 & 152.4531 & 150.5245 & 1.9285 & 1.265 & $\begin{array}{c}\text { Witness in } \\
\text { KOH 100g/l }\end{array}$ \\
\hline 5 & 157.4290 & 157.3744 & 156.5865 & 0.7879 & 0.5007 & $\begin{array}{c}\text { Sample in } \\
18 \% \mathrm{HCl}\end{array}$ \\
\hline 6 & 121.5156 & 120.6179 & 120.0884 & 0.5295 & 0.439 & $\begin{array}{c}\text { Sample in } \\
18 \% \mathrm{HCl}\end{array}$ \\
\hline 7 & 139.6769 & 139.5951 & 138.9563 & 0.6388 & 0.457 & $\begin{array}{c}\text { Sample in } \\
\text { KOH 100g/l }\end{array}$ \\
\hline 8 & 114.2470 & 114.1034 & 113.666 & 0.4374 & 0.3833 & $\begin{array}{c}\text { Sample in } \\
\text { KOH 100g/l }\end{array}$ \\
\hline
\end{tabular}

\section{III.4. Frost-thaw resistance}

The tests were done according to SR EN ISO 77218:2003 [28], on cubes of composition BPC4. Three cubes of $70 \mathrm{~mm}$ size were subjected to frost-thaw cycles and other 3 cubes were kept as witness, Tab. 4.
From the Table 4 it results: $30.318 \mathrm{MPa}$ - compressive strength of untested samples and 29.636 MPa - compressive strength of samples subjected to frost-thaw cycles. The loss in compressive strength was $2.249 \%$.

After 50 frost-thaw cycles in the temperature interval $15^{\circ} \mathrm{C}$ and $20^{\circ} \mathrm{C}$, the polymer concrete with tires powder had a loss of compressive strength of $2.249 \%$, Table 4 , that means a very good behaviour to frost-thaw cycles.

TABLE IV. DETERMINATION OF FROST-THAW RESISTANCE

\begin{tabular}{|c|c|c|c|}
\hline No. & Force, N & $\begin{array}{c}\text { Failure stress for } \\
\text { tested samples, } \\
\mathrm{MPa}\end{array}$ & $\begin{array}{c}\text { Failure stress } \\
\text { for untested } \\
\text { samples, MPa }\end{array}$ \\
\hline 1 & 147128 & - & 30.026 \\
\hline 2 & 144637 & - & 29.518 \\
\hline 3 & 153910 & - & 31.410 \\
\hline 4 & 150704 & 30.756 & - \\
\hline 5 & 141272 & 28.831 & - \\
\hline 6 & 143668 & 29.320 & - \\
\hline 7 Witness & 347890 & 70.998 & - \\
\hline 8 Witness & 337455 & 68.868 & - \\
\hline 9 Witness & 342652 & 69.929 & 34.009 \\
\hline 10 Witness & 166644 & - & 31.862 \\
\hline 11 Witness & 156125 & - & 35.026 \\
\hline 12 Witness & 171626 & - & \\
\hline
\end{tabular}

The witness polymer concrete subjected to the same number of frost-thaw cycles had a loss of compressive strength of $51.911 \%$.

The witness polymer concrete had a weaker behaviour to frost thaw cycles, compared to that of polymer concrete with tire powder.

\section{III.5. Water adsorption}

The tests were done according to SR EN ISO 105453:1999 [29] on three samples with initial mass between: $113.7133 \div 155.4960 \mathrm{~g}$.

The water adsorption by the boiling method for polymer concrete had the average value $0.6745 \%$, Table 5 .

TABLE V. DETERMINATION OF WATER ADSORPTION

\begin{tabular}{|c|c|c|c|c|c|}
\hline No. & $\begin{array}{c}\text { Initial } \\
\text { Mass, } \mathbf{g}\end{array}$ & $\begin{array}{c}\text { Constant } \\
\text { Mass, } \mathbf{g}\end{array}$ & $\begin{array}{c}\text { Wet } \\
\text { Mass, } \mathbf{g}\end{array}$ & $\begin{array}{c}\text { Difference of } \\
\text { mass, g }\end{array}$ & $\begin{array}{c}\text { Water } \\
\text { adsorption, } \%\end{array}$ \\
\hline 1 & 140.2879 & 140.1854 & 140.8375 & 0.6521 & $\begin{array}{c}0.4652- \\
\text { Witness }\end{array}$ \\
\hline 2 & 132.7521 & 132.6292 & 133.2965 & 0.66725 & $\begin{array}{c}0.5031- \\
\text { Witness }\end{array}$ \\
\hline 3 & 120.7565 & 120.6393 & 121.4928 & 0.8535 & 0.7075 \\
\hline 4 & 113.7133 & 113.6061 & 114.6296 & 0.7234 & 0.6367 \\
\hline 5 & 139.1093 & 138.9927 & 139.8682 & 0.8755 & 0.6298 \\
\hline 6 & 156.6115 & 155.4960 & 156.622 & 1.126 & 0.7241 \\
\hline
\end{tabular}

The water adsorption by boiling into water at $80^{\circ} \mathrm{C}$ during 2 hours and cooling in water during 2 hours and 15 minutes, so a total immersion in liquid of about 4 hours and 15 minutes was a hardness test for any building material. For average value of water adsorption of $0.6745 \%$ for polymer concrete with tire powder, it can appreciate that this material behaves well at this physical test, showing the possibility to be used in natural situation with water presence. 
Proc. of the Fourth International Conference on Advances in Civil, Structural and Environmental Engineering - ACSEE 2016. Copyright (C) Institute of Research Engineers and Doctors. All rights reserved.

ISBN: 978-1-63248-114-6 doi: 10.15224/ 978-1-63248-114-6-57

\section{III.6. Microstructure of Polymer Concrete}

Scanning electron microscope (SEM) Vega Tescan analysis running at $30 \mathrm{kV}$ and selenium detectors were used to investigate concrete morphology [30]. An Ag sputter


coating was applied on the surface of the specimens to provide greater depth of image, Figure 3.

The picture from Figure 3 clearly shows the presence of voids having maximum diameter of about $40 \mu \mathrm{m}$ in the polymer concrete. The resin is homogeneous in the mass and covers the aggregates, but in some places the polymer is agglomerated.
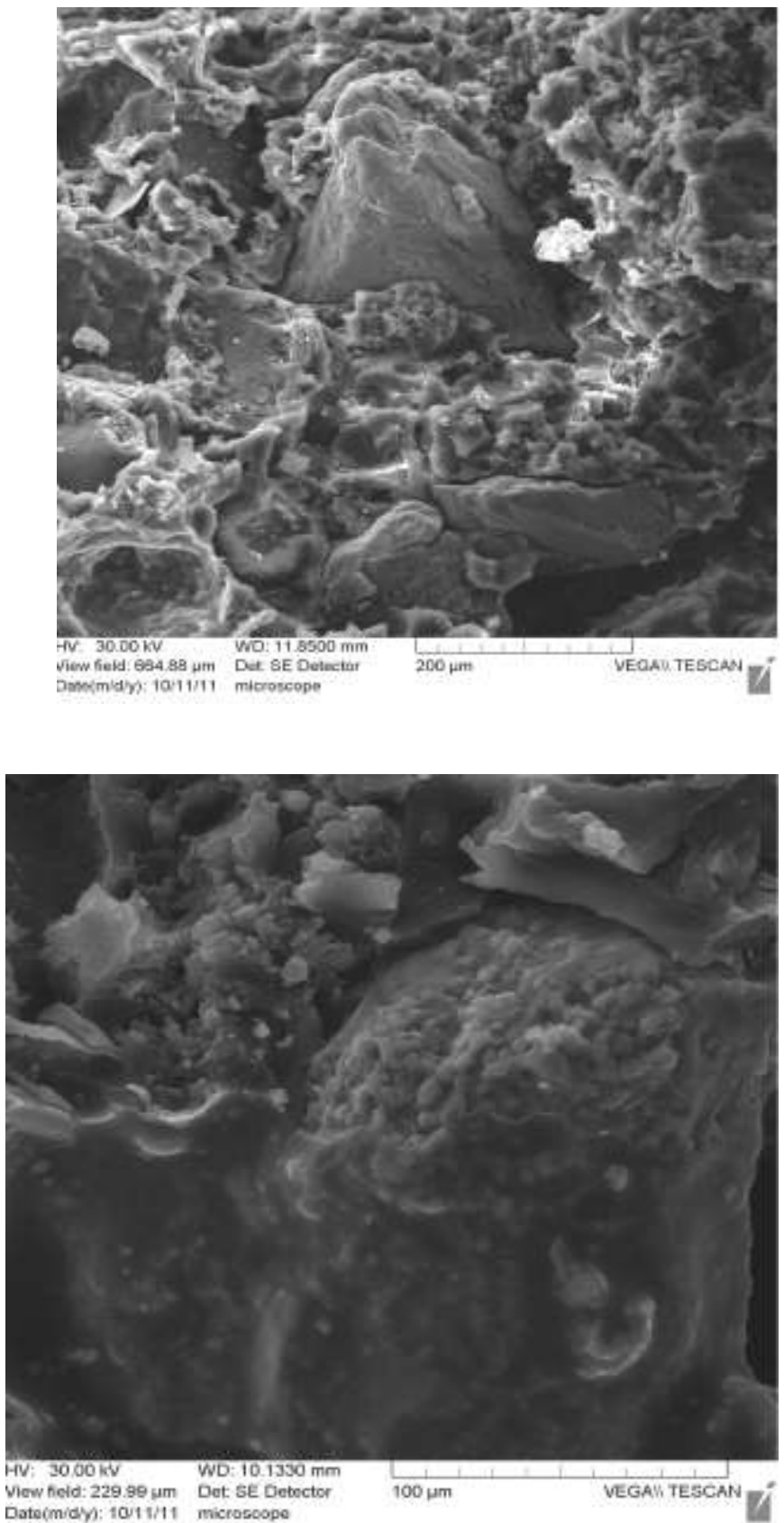

Fig. 3 Scanning electronic microscopy for polymer concrete samples with epoxy resin, tires waste and aggregate

\section{Conclusions}

Polymer concrete was obtained from epoxy resin, two sorts of aggregate $0-4 \mathrm{~mm}$ and $4-8 \mathrm{~mm}$ and tire waste powder as filler. The new material was characterized by experimental determining of physical and durability properties.
Thermo-physical tests: density, thermal shock strength, chemical resistance, frost-thaw resistance and water adsorption have shown a very good behaviour of epoxy concrete with tires powder subjected to different types of aggressive agents, compared with that of witness polymer concrete, without filler.

Using the scanning electron microscope the microstructure of polymer concrete with tires powder was 
Proc. of the Fourth International Conference on Advances in Civil, Structural and Environmental Engineering - ACSEE 2016. Copyright $(\subseteq$ Institute of Research Engineers and Doctors. All rights reserved.

ISBN: 978-1-63248-114-6 doi: 10.15224/ 978-1-63248-114-6-57

studied. The microstructure presents some resin agglomerations and voids, in the case of a high content of resin. The homogeneity of the mix depends very much on the time of mixing, the order of mixing the components, the compaction of the mix, all these influencing very much the test results.

The use of tires wastes in polymer concrete may help to improve the environment by elimination of a pollutant and to obtain a new composite material for construction industry.

This new composite which uses powder of waste tires is a lightweight concrete, with good durability properties, which can successfully replace the cement concrete in specific applications such as: prefabricated unit for sound protection, thermal insulation, floors for chemical industry, pavements, etc.

\section{Acknowledgments}

The authors thank the Executive Agency for Higher Education, Research, Development and Innovation Funding, Bucharest and the Government of Romania for funding the studies under New eco-concrete to increase energy efficiency in agro-zootehnical buildings.

\section{References}

[1] M. Bravo, and J. de Brito, "Concrete made with used tyre aggregate: durability-related performance", J. Cleaner Prod. 25 (2012), pp. 4250.

[2] N. Wang, J. Park, and T. Ellis, "Utilization of the used tire rubber particle in hydrogen sulfide control", J. Mater. Cycles Waste Manag. 16 (2014), pp. 475-481.

[3] K. Collins, A. Jensen, J. Mallinson, V. Roenelle, I. and Smith, "Environmental impact assessment of scrap tyre artificial reef", ICES J. Marine Sci. 59 (2002), pp. 243-249.

[4] B. Adhikari, D. De, and S. Maiti, "Reclamation and recycling of waste rubber", Prog. Polym. Sci. 25 (2000), pp. 908-948.

[5] S. Pendhari, T. Kant, and Y. Desai, "Application of polymer composites in civil construction: A general review", Compos. Struct. 84 (2008), pp. 114-124.

[6] M. Heidari-Rarani, M. Aliha, M.M. Shokrieh, and M.R. Ayatollahi, "Mechanical durability of an optimized polymer concrete under various thermal cyclic loadings-An experimental study", Constr. Build. Mater. 64 (2014), pp. 308-315.

[7] W. Lokuge, and T. Aravinthan, "Effect of fly ash on the behaviour of polymer concrete with different types of resin", Mater. Design 51 (2013), pp. 175-181.

[8] X. Huang, R. Ranade, W. Ni, and V. Li, "On the use of recycled tire rubber to develop low E-modulus ECC for durable concrete repairs", Constr. Build. Mater. 46 (2013), pp. 134-141.

[9] J.P. Gorninski, D.C. Dal Molin, and C.S. Kazmierczak, "Comparative assessment of isophtalic and orthophtalic polyester polymer concrete: Different costs, similar mechanical properties and durability", Constr. Build. Mater. 21 (2007), pp. 546-555.

[10] M. Frigione, "Concrete with polymers". In Eco-Efficient Concrete Edited by: F. Pacheco-Torgal, S. Jalali, J. Labrincha, V. M. John, Elsevier, 2013, pp. 386-436.

[11] M. Barbuta, M. Harja, I. Cretescu, and G. Soreanu, "Influence of wastes content on properties of polymer concrete", 7th Int. Symp. Cement Based Mater. Sust. Agr., Canada, 18-21 Sept. (2011) 358364.
[12] M. Barbuta, R.M. Diaconescu, and M. Harja, "Using Neural Networks for Prediction of Properties of Polymer Concrete with Fly Ash", J. Mater.Civil. Eng. 24 (2012), pp. 523 -528.

[13] R.M. Diaconescu, M. Barbuta, and M. Harja, "Prediction of mechanical Properties of Polymer Concrete with tyre rubber Using Neural Networks”, Mater. Sci. Eng. B 178 (2013), pp. 1259-1267.

[14] M. Barbuta, M. Harja, and I. Baran, "Comparison of Mechanical Properties for Polymer Concrete with Different Types of Filler", J. Mater. Civ. Eng. 22 (2010), pp. 696-701.

[15] B.W. Jo, S.K. Park, and D.K. Kim, "Mechanical properties of nanoMMT reinforced polymer composite and polymer concrete, Constr. Build. Mater. 22 (2008), pp. 14-20.

[16] G. Ahmetli, A. Gungor, and S. Kocaman, "Epoxy composites based on inexpensive tire waste filler", AIP Conference vol. 599 (2014), pp. 346-349.

[17] B. Yesilata, Y. Isıker, and P. Turgut, "Thermal insulation enhancement in concretes by adding waste PET and rubber pieces", Constr. Build. Mater. 23 (2009), pp. 1878-1882.

[18] Siddique R (2014) "Utilization (recycling) of iron and steel industry by-product (GGBS) in concrete: strength and durability properties". J Mater Cycles Waste Manag 16, pp. 460-467.

[19] M. Harja, and M. Barbuta, "Influence of different additions on frostthaw and chemical resistance of polymer concrete", Adv. Sci. Lett., 19 (2013), pp. 455-459.

[20] M. Barbuta, M. Harja, and G. Ciobanu, "Mechanical properties of polymer concrete containing tire waste powder", J. Food Agric. Environ. 12 (2014), pp. 1186-1190.

[21] A. Benazzouk, O. Douzane, K. Mezreb, B. Laidoudi, and M. Queneudec, "Thermal conductivity of cement composites containing rubber waste particles: Experimental study and modelling", Constr. Build. Mater. 22 (2008), pp. 573-579.

22] C. Lin, Yu-J. Hong, and A. Huc, "Using a composite material containing waste tire powder and polypropylene fiber cut end to recover spilled oil", Waste Manag. 30 (2010), pp. 263-267.

[23] SR EN 771-3: 2004 - "Specification for masonry units - Part 3: Aggregate concrete masonry units (Dense and light-weight aggregates)".

[24] SR EN 772-13: 2001 - "Methods of test for masonry units - Part 13: Determination of net and gross dry density of masonry units (except or natural stone) ".

[25] SR EN 771-3:2004 - "Specification for masonry units - Part 3: Aggregate concrete masonry units (Dense and light-weight aggregates)".

[26] SR EN ISO 10545-9:2000 - "Ceramic tiles. Part 9: Determination of resistance to thermal shock".

[27] SR EN ISO 10545-13:2001 - "Ceramic tiles. Part 13: Determination of chemical resistance".

[28] SR EN 772-18:2003 - "Methods of test for masonry units - Part 18: Determination of freeze-thaw resistance of calcium silicate masonry units.

[29] SR EN ISO 10545-3:1999 - "Ceramic tiles. Part 3: Determination of water absorption, apparent porosity, apparent relative density and bulk density".

[30] M. Barbuta, M. Harja, and D. Babor, "Concrete polymer with fly ash. Morphologic analysis based on scanning electron microscopic observations". Rom. J. Mat. 40 (2010), pp. 3-14.

Bucur Roxana Dana

University of Agricultural Sciences and Veterinary Medicine in Iasi Romania

Barbuta Marinela, Harja Maria, Baran Irina

"Gheorghe Asachi" Technical University of Iasi

Romania 